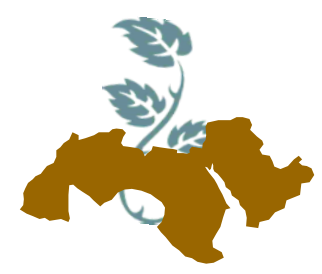

Arab Univ.

J. Agric. Sci., Ain Shams Univ., Cairo, 26(2), 691 - 699, 2018

\title{
EVALUATION OF SOME FUNGICIDES AND BIOCONTROL AGENTS FOR CONTROLLING OF ALTERNARIA ROT ON CITRUS FRUITS
}

\author{
Shehata $^{2}$, A.S.F.; A.K. Mohammed ${ }^{2}$; A.A.A. Mosa ${ }^{1}$ and M.K. Ali ${ }^{1}$ \\ 1- Plant Pathology Dept., Fac. of Agric., Ain-Shams Univ. Cairo, Egypt \\ 2- Fruit and Wood Trees Res. Dis. Dept., Plant Pathology Res. Inst., Agric. Res. Center, Giza, \\ Egypt
}

[54]

Keywords: Citrus, fruit-rot, chemical control, biological control and Alternaria citri

\section{ABSTRACT}

In this study, chemical and bio-control agents were evaluated for their efficiency to control of citrus fruit-rot disease caused Alternaria citri (K2) both, in vitro and in vivo trials. The most effective fungicides were score, montro and Iprodione compared with other fungicides depend on Ec50 and Ec90. While, the fungicide Pyraclostrobine had moderate effect on linear growth of $A$. citri. Meanwhile, the Coprax, Coprareekh and Azoxystrobine were the least effective fungicide at Ec90. Trichoderma harzianum and Bacillus subtilis tested showed antagonistic action effect to a highly pathogenic isolate of Alternaria citri, with different degrees of inhibition. T. harzianum was the most effective compared with $B$. subtilis, in vitro trials. Also, all fungicides were evaluated on incidence of citrus fruit rot disease in vivo trials. The disease incidence was reduced, but with different degrees. In addition, using $T$. harzianum, $B$. subtilis, $B$. megaterium (Bio-ARC) and Trichoderma album (Bio-Zeid) decreased incidence of citrus fruit rot disease. On the other side, T. harzianum showed the highest suppressive effect against citrus fruit rot pathogen. Generally, all tested fungicides and bio-agents were effective against the causal fungus in vitro and in vivo trials, but with different degrees.

\section{INTRODUCTION}

Citrus trees (Citrus sp.) within the genus citrus belongs to family Rutaceae sub family Aurantoideae. It is cultivated world wide. Citrus is liable to infection by several fungal, bacterial and viral diseases, in addition to physiological disorders (ElZayat, et al 1983, Commonwealth of Australia 2002 and Manner et al 2006). Fungal diseases, especially Alternaria causing many diseases on citrus trees i.e. fruit rot of citrus fruit, leaf spot brown spot, stem end rot and mancha foliar disease (Brown, 1994; Brown \& Eckert, 2000 and Timmer et al 2003).

Foliar fungicide applications are usually necessary to produce fruit with good external quality in areas where Alternaria brown spot is common. Studied the effect of Copper fungicides are the only material registered for control of this disease, but they are not highly effective. Since captafol has a long residual and is redistributed, few applications were needed for good disease control. However, this product is no longer registered in most areas due to health concerns (Timmer, 1998 and Vicent et al 2007, 2009). Iprodione is also very effective for disease control (Whiteside, 1979; Solel et al 1996; Bhatia et al 2003 and Timmer, et al 2003). Other fungicides that are effective and registered in Israel such as dithiocarbamates, triazoles, and famoxadon. Also, the strobilurin fungicides have been evaluated and proven effective for control of brown spot. In addition, Azoxystrobin and pyraclostrobin are generally more effective than trifloxystrobin (Timmer et al 2003; Reis et al 2006 and van-Zyl et al 2013). The growth of $A /$ ternaria alternata, Penicillium digitatum and Alternaria citri fungi were greatly suppressed by Difenoconazole at $150 \mathrm{ppm}$ (Monir and Salaheldin, 2016).

Also, studied the effect of $T$. harzianum was the most antagonistic to the tested Alternaria isolate causing citrus brown spot. Also, T. viride and $T$. koningii exhibited an antagonistic activity more 
than that recorded for $T$. album and G. roseum. In vitro trials all Trichoderma species namely, Trichoderma viz., Trichoderma viride, Trichoderma aureoviride, Trichoderma reesei, Trichoderma koningii and Trichoderma harzianum were significantly reduced the biomass of Alternaria citri the causal agent of the citrus black rot disease on a broad range of citrus cultivars. In addition, using Bacillus subtilis against species of Alternaria was the most antagonistic (Singh \& Deverall 2006; Sharma, et al 2009 and Murtaza et al 2012). Biological control of plant pathogens by microorganisms has been considered a more natural and environmentally acceptable, safety, active, alternative to the existing chemical treatment methods and economically the bio-agents cost less than fungicides (Siameto et al 2010).

This work was planned to test some fungicides and bio-control agents to control fruit rot disease of citrus.

\section{MATERIALS AND METHODS.}

\section{Source of pathogenic fungus}

Isolate of $A$. citri (code $\mathrm{K} 2$ ) was isolated from infected citrus fruit with typical symptoms of rot disease. Infected fruits were collected from Qaliobiya Governorate. The fungus was microscopically identified on the basis cultural and microscopic characteristic also, confirmed by Mycology and Plant Dis. Survey Department, Plant Pathol. Res. Inst. (ARC).

\section{Source of bioagents}

Isolate of Trichoderma harzianum was isolated during the isolation of the causal pathogens of citrus fruit rot disease this isolate was identified by Mycology and Plant Dis. Survey Dept., Plant Pathol. Res. Inst., (ARC) Giza Egypt.

Isolate of Bacillus subtilis was obtained from Bacterial Dis., Res., Dept., Plant Pathol. Res. Inst., (ARC) Giza Egypt. Effect of these bioagents against the causal pathogen of citrus fruit rot disease, i.e. ( $A$. citri), this pathogenic isolate were isolated from infected citrus fruit and tested in vitro and in vivo trials.

\section{Source of bio-agents formula}

Three bioagents namely, Bacillus subtilis and Bacillus spp., (Omega) which contains $3 \times 10^{7}$ to $3.1 \times 10^{7} \mathrm{cfu} / \mathrm{g}$ and obtained from ARC, Bacillus megaterium (Bio ARC) which contains $25 \times 10^{6}$ cfu $/ g$ and Trichoderma album (Bio Zeid) contains of $10 \times 10^{6}$ spores $/ g$ were provided by Plant Pathol. Res. Inst., (ARC) Giza, Egypt. All these bioagents were evaluated against the tested pathogen and added as suspensions at the rate of $5 \mathrm{~g} /$ liter of water.

\section{Fungicides}

Efficiency of seven fungicides differed in their active ingredients and chemical groups, mentioned in (Table 1) to control the causal pathogen of citrus fruit-rot disease in vitro and in vivo trials.

\section{In vitro}

\subsection{Preparation of fungicides concentration}

Concentrations they are prepared for each fungicide according to recommended dose two concentrations before and two concentrations after recommended dose were prepared for each fungicide, according to Sharvell (1962). The concentrations were added to PDA medium (poisons media) as the described method by Al-Hassan and Najlah, (1982) to determine their ability to inhibit the mycelial growth of the tested pathogen. Reduction percentage of fungal growth was calculated according to the following formula.

$$
\text { Reduction }(\%)=\frac{\text { Control-treatment }}{\text { Control }} \times 100
$$

Table 1. Tested fungicides against pathogenic isolate of Alternaria rot of citrus fruit disease

\begin{tabular}{|c|c|c|c|}
\hline $\begin{array}{c}\text { Commercial name } \\
\text { WP. }\end{array}$ & Common name & $\begin{array}{c}\text { Recom- } \\
\text { mended } \\
\text { Dose }\end{array}$ & $\begin{array}{c}\text { Compa- } \\
\text { ny, type }\end{array}$ \\
\hline $\begin{array}{c}\text { Coperrarikh 50\% } \\
\text { Montoro (30\%) EC. }\end{array}$ & $\begin{array}{c}\text { Copper oxychlo- } \\
\text { ride } \\
\text { Propaconazol- } \\
\text { Difenoconazole }\end{array}$ & $3 \mathrm{~g} / \mathrm{L}$ & $\begin{array}{c}\text { Iccta } \\
\text { (contact) }\end{array}$ \\
Score (250\%) EC. & $\begin{array}{c}\text { Difenoconazole } \\
\text { Iprodione (50\%) G }\end{array}$ & $0.5 \mathrm{ml} / \mathrm{L}$ & Star-chem \\
Iprodione & $1.5 \mathrm{~g} / \mathrm{L}$ & PROPLAN \\
$\begin{array}{c}\text { Coprax 77\% WP } \\
\text { Azoxystrobine } \\
\mathbf{2 5 \% S C}\end{array}$ & $\begin{array}{c}\text { Copper hydrox- } \\
\text { ide }\end{array}$ & $2.50 \mathrm{~g} / \mathrm{L}$ & \\
$\begin{array}{c}\text { Pyraclostrobine } \\
\mathbf{1 1 . 2 \%} \text { EC }\end{array}$ & Pyraclostrobine & $2 \mathrm{ml} / \mathrm{L}$ & BASF \\
\hline
\end{tabular}



rot on citrus fruits

\subsection{Preparation inoculum of T. harzianum and solid agar bioassay}

T. harzianum was grown on PDA medium. To test the antagonistic effect of the two bio-agents under study in vitro on the linear growth of the causal pathogen of citrus fruit rot disease, the following method was used. Petri dishes $(9 \mathrm{~cm}$ in diameter), each contained $20 \mathrm{ml}$., of PDA medium were inoculated with discs (5 $\mathrm{mm}$ in diameter) of the tested pathogen, taken from 7day-old cultures. The discs were placed near of the edge of each Petri-dish. At the same time plates were inoculated with equal discs of $T$. harzianum. Five plates were used as replicates for each treatment. In-vitro biological activity of $T$. harzianum on $A$. citri was investigated by double cultures on the potato dextrose agar. They were incubated at $28 \pm 1{ }^{\circ} \mathrm{C}$ and the diameter of the colonies was measured for 10 days.

\subsection{Efficacy of antagonistic bioagent against A. citri (code K2)}

A- In diffusible metabolites, investigations were maintained with the variants:

1- Placing the fragments of test fungus and pathogen on the separated half of a media. The discs of test fungus and pathogen were placed near the edge of each petri-dish. At the same time plates were inoculated with equal discs of $T$. harzianum on the same distance of appoint side.

B- In volatile metabolites investigations, fragments of the tested Alternaria citri (Code, K2) and $T$. harzianum was placed in the center of two separate PDA plates sealed with parafilm, so, the $T$. harzianum was in the under plate and, the Alternaria isolate was in upper plate. There were two controls ( $T$. harzianum and $A$. citri) in an inverted position. After the period of incubation, micro observations were made of the Alternaria isolate in the two kinds of double cultures (Gveroska and Ziberoski, 2012).

\subsection{Preparation inoculum of $B$. subtilis}

Isolate of Bacillus subtilis was grown on nutrient agar medium (NA). Antagonistic effect of $B$. subtilis on the linear growth of the same pathogen was tested in vitro. The tested bacterium was streaked on PDA plate near of the edge of each Petri dish, while the inoculation with the tested pathogen was done as mentioned before in the second half of each dish. All plates were incubated at $28 \pm 1 \stackrel{\circ}{\circ}$ c until the growth in control treatment reached the edge of the plates. Reduction percentage of fungal growth was calculated according to the formula as mentioned before.

\section{In vivo}

\subsection{Fungicides}

The above mentioned fungicides were used sprayed on citrus old-shoots of Navel orange carrying flowers at Qaliubiya governorate. These fungicides were utilized as suspension and sprayed as mentioned before, at their recommended dose per liter of water.

\subsection{Biological control}

\subsubsection{Preparation of antagonists inocula:}

These trials were carried out under open field conditions were utilized to evaluate the efficiency of the bioagents $T$. harzianum, Bio-ARC (B. megaterium), Bio Zeid ( $T$. album) the bioagents Bio-ARC (B. megaterium $6 \%\left(25 \times 16^{6}\right.$ bacterial cells $\left./ g\right)$ or Bio-Zeid ( T. album, $2.5 \%\left(10 \times 10^{6}\right.$ spores $\left./ g\right)$ and (Bacillus sp., B. subtilis, contains $3 \times 10^{7}$ to $3.1 \times 10^{7}$ $\mathrm{cfu} / \mathrm{g}$ ) omega for controlling of pathogenic fungus associated with citrus fruit rot disease.

\subsubsection{Preparation inoculum of $T$. harzianum}

The inoculum of $T$. harzianum (the fungal isolate) was prepared by growing on autoclaved liquid medium (Czapek's liquid medium CLM (Jakovljević et al 2015). The inoculation was carried out with $5 \mathrm{~mm}$ in diameter fungal disks taken from the margin of 7 days old culture. The inoculated flask were incubated at $28 \pm 1{ }^{\circ} \mathrm{C}$ for 15 days, $T$. harzianum was sprayed on the tree at the rate of $10^{8} \mathrm{spore} / \mathrm{ml}^{-1}$ (Arrebola et al 2010).

\subsubsection{Preparation inoculum of $B$. subtilis}

B. subtilis was prepared by grown on liquid medium ( $5 \mathrm{~g}$ peptone, $3 \mathrm{~g}$ beef extract and $10 \mathrm{glu}$ cose per liter) was sprayed on the tree at the rate of $10^{7} \mathrm{cfu} / \mathrm{ml}^{-1}$. Also, a number of trees were inoculated with the bioagents, each alone, and the same number was left free from the bioagent as control treatment. 


\subsubsection{Preparation inoculum of formula}

In the second method, the bioagents were sprayed on the trees during flowering. While, $B$. megaterium (Bio-ARC) T. album (Bio-Zeid) and $B$. subtilis, Bacillus spp., (Omega) were sprayed on tree as suspensions at the rate $5 \mathrm{~g}$ / liter of water.

\section{Statistical analysis}

Data were statistically analyzed using complete randomized design according to Gomez and Gomez, (1984). The bioassay average in vitro trial was compared by least significant differences (LSD) test at level $5 \%$. Chemical and biological in vivo trials the percentage data were transformed into arcsine angles to produce approximately constant variance before carrying out variance (ANOVA). The significance of various treatments was evaluated by Duncan's multiple range tests $(p<0$, 05\%) (Duncan, 1955).

\section{RESULTS}

\section{a. Effect of chemical control, in vitro.}

Data presented in Table (2) indicate that all the tested fungicides were affected on the linear growth of the tested fungi. Generally, the magnitude of effect was increased by increasing the concentration of all the tested fungicides. The most significantly effective fungicides were Score, Montro and Iprodione and the reduced the growth of Alternaria citri isolate(code K2) which inoculated on (PDA medium) plate was reached around recommended dose for each fungicide was used against Alternaria citri isolate (code K2) under study. Also, the results in Table (2) show that,
Score, Montro and Iprodione fungicides were the most effective fungicides against Alternaria isolate (code K2) based on Ec. 90, where the linear growth the fungus $96.89,78.42$ and 329.01 respectively. Whilst, Pyraclostobine fungicide was moderate effective fungicide against Alternaria isolate (code K2) at Ec. 90, where the linear growth the fungus 5429.62. While, Coprax, Coprekh, and Azoxystrobine were the lowest effective fungicides compared with other fungicides against Alternaria isolate (code K2) at Ec. 90, where the result were found to be $4741.49,3165.96$ and 1000.00 , respectively.

\section{b. Effect of bio-agents, in vitro}

\section{Interaction between the bio-agents with $\boldsymbol{A}$. citri isolate (K2) by direct contact}

The obtained data in Table (3) show that $T$. harzianum was the most effective bio-agents against $A$. citri isolate (code $\mathrm{K} 2$ ) causing citrus fruit rot disease compared with $B$. subtilis. The reduction percentage was $86.66 \%$ when $T$. harzianum was used with $\mathrm{K} 2$. Whilst, the reduction percentage was $69.44 \%$ when $B$. subtilis was used with K2. On the other side, obtained data show that $B$. subtilis was the lowest effective than $T$. harzianum with $A$. citri isolate (code $\mathrm{K} 2$ ). Also, data presented in Table (3) revealed that, volatile (metabolism) of $T$. harzianum was more effect on linear growth of $A$. citri the causal pathogen of citrus fruit rot than $B$. subtilis but, less than when $T$. harzianum inoculated in the same plate with $A$. citri. While, the antagonistic action was highly significant and occurred by $T$. harzianum with $\mathrm{K} 2$ isolate of $A$. citri the causal pathogen of citrus fruit rot disease and the reduction percentage was $86.44 \%$.

Table 2. Effect of using some fungicide on the mycelial growth of $A$. citri (Code K2) the causal pathogen of citrus fruit rot disease in vitro trial.

\begin{tabular}{|l|c|c|c|c|}
\hline \multicolumn{1}{|c|}{ Fungicides } & Ec. 50 & Ec. 90 & Reg. Equation & $\mathbf{R}^{\mathbf{2}}$ \\
\hline Score & $\mathbf{2 0 . 4 4}$ & $\mathbf{9 6 . 8 9}$ & Probit=1.894 $\times-2.513$ & 0.865 \\
Montro & $\mathbf{1 6 . 0 4}$ & $\mathbf{7 8 . 4 2}$ & Probit= $1.857 \times-2.762$ & 0.883 \\
Iprodione & $\mathbf{7 4 . 0 3}$ & $\mathbf{3 2 9 . 0 1}$ & Probit= $1.976 \times+1.306$ & 0.819 \\
Coprarrekh & $\mathbf{1 5 1 1 . 3 9}$ & $\mathbf{5 4 1 9 . 6 2}$ & Probit= $2.308 \times-2.338$ & 0.968 \\
Coprax & $\mathbf{1 5 2 2 . 8 6}$ & $\mathbf{4 7 4 1 . 4 9}$ & Probit= $2.595 \times-3.259$ & 0.993 \\
Pyraclostrobine & $\mathbf{1 6 0 . 7 9}$ & $\mathbf{3 1 6 5 . 9 6}$ & Probit= $0.989 \times+2.818$ & 0.953 \\
Azoxystrobine & $\mathbf{2 6 8 . 2 7}$ & $\mathbf{1 0 0 0 . 0 0}$ & Probit=2.24 x-0.440 & 0.583 \\
\hline
\end{tabular}

Reg. Equation=Regression equation between Log concentration $(\log Y)$ and the probit of the \% of growth inhibition (X).

Coeff. Error $\left(\mathbf{R}^{2}\right)=$ Correlation coefficient of $Y$ and $X$ 

rot on citrus fruits

Table 3. Effect of Trichoderma harzianum and $B$. subtilis as bio agents on mycelial growth of $A$. citri isolate the casual pathogen of citrus fruit rot disease in vitro trial.

\begin{tabular}{|c|c|c|c|}
\hline Bioagent & Reaction & $\begin{array}{c}\text { Growth } \\
\text { (cm) }\end{array}$ & ${ }^{*}$ Red. \% \\
\hline \multirow[t]{2}{*}{ T. harzianum } & Direct contact & 1.20 & 86.66 \\
\hline & Indirect contact & 1.22 & 86.44 \\
\hline Bacillus subtilis & Direct contact & 2.75 & 69.44 \\
\hline Control & & 9.00 & 0.00 \\
\hline \multicolumn{2}{|c|}{ LSD. at level $5 \%$ for treatment } & $\begin{array}{c}\left({ }^{*} \mathrm{~T}\right)= \\
0.51553\end{array}$ & $\begin{array}{c}\left({ }^{*} \mathrm{~B}\right)= \\
0.84802\end{array}$ \\
\hline
\end{tabular}

${ }^{*}$ Red. $=$ Reduction percentage

${ }^{*} \mathrm{~T}=T$. harzianum $\quad{ }^{*} \mathrm{~B}=$ Bacillus subtilis

\section{c. Effect of chemical control, in vivo studies}

The aforementioned fungicides were tested for their efficiency to control the disease under field conditions. Results in Table (4) show that these fungicides differed in their effect on $A$. citri isolate (K2). Alternaria citri was highly affected by using selective fungicides namely, Score, Montoro and Iprodione and the percentage of the disease incidence in the field was decreased and the average of the disease incidence was reach about $(4,4$ and $8 \%$ ) respectively, also, the percentage of disease incidence was reach about $(5.31,5.31$ and $10.63 \%)$, respectively.

Table 4. Effect of some fungicides on disease incidence of citrus fruit rot in vivo

\begin{tabular}{|c|c|c|c|c|}
\hline Treatment & $\begin{array}{c}\text { Dis., Incid. } \\
\text { Average }\end{array}$ & In T & ${ }^{*} \mathbf{R} . \%$ & H T \\
\hline Coprareekh & 20 & $23.79 \mathrm{bc}$ & 80.00 & $66.21 \mathrm{ab}$ \\
Iprodione & 8 & $10.63 \mathrm{c}$ & 92.00 & $79.37 \mathrm{a}$ \\
Coprax & 20 & $23.79 \mathrm{bc}$ & 80.00 & $66.21 \mathrm{ab}$ \\
Score & 4 & $5.31 \mathrm{c}$ & 96.00 & $84.69 \mathrm{a}$ \\
Montoro & 4 & $5.31 \mathrm{c}$ & 96.00 & $84.69 \mathrm{a}$ \\
Pyraclostrobine & 12 & $13.16 \mathrm{c}$ & 88.00 & $76.84 \mathrm{a}$ \\
Azoxystrobine & 36 & $36.47 \mathrm{~b}$ & 64.00 & $53.53 \mathrm{~b}$ \\
Cont A. with W & 76 & $63.68 \mathrm{a}$ & 24.00 & $26.32 \mathrm{c}$ \\
\hline
\end{tabular}

* The data were transformed using arcsine formula.

${ }^{*} \mathrm{R}=$ Reduction percentage of the disease incidence

${ }^{*}$ In $T=$ Transformed data for disease incidence

${ }^{*} \mathrm{H} \mathrm{T}=$ Transformed data for fruits healthy unit

While, Pyraclsotrobin was moderate effective when used against the pathogenic Alternaria isolate and the reduction percentage of disease incidence was (88\%) and the disease incidence aver- age was (12\%). Whilst, Coprax, Coprareekh, and Azoxystrobin were the lowest effective fungicides against the highly pathogenic isolate of Alternaria (K2) were selective under study.

\section{d. Effect of bio-agents in vivo:}

Data presented in Table (5) reveal that, T. harzianum was the most effective bio-agent against tested casual pathogen of citrus fruit rot disease Followed by $B$. subtilis. While, Bacillus sp., B. subtilis (omega) and B. megaterium (Bio-ARC) and $T$. album (Bio-Zeid) were the lowest bioagents, respectively. Application of bioagents led to decrease of the disease incidence to $84 \%$ with $T$. harzianum followed by $B$. subtilis whereas the reduction percentage of disease incidence was76\%. Whilst, B. megaterium (Bio-ARC), $T$. album (Bio-Zeid), and Bacillus sp., B. subtilis (omega) were the lowest effective bio-agents against $A$. citri isolate causing citrus fruit rot disease, whereas the percentage of disease reduction was reach about $(60,68$ and $72 \%)$ respectively.

Table 5. Effect of bioagents on the disease incidence of citrus fruit rot, under field conditions

\begin{tabular}{|c|c|c|c|c|}
\hline Treatment & $\begin{array}{c}\text { Dis., } \\
\text { Incid. } \\
\text { Average }\end{array}$ & ${ }^{*} \mathbf{I n} \mathbf{T}$ & ${ }^{*} \mathbf{R} . \%$ & ${ }^{*} \mathbf{H ~ T}$ \\
\hline Bacillus & 24 & $26.32 \mathrm{bc}$ & 76 & $63.68 \mathrm{ab}$ \\
Trichoderma & 16 & $18.47 \mathrm{bc}$ & 84 & $71.53 \mathrm{ab}$ \\
Omega & 28 & $28.63 \mathrm{bc}$ & 72 & $61.38 \mathrm{ab}$ \\
Bio-zied & 32 & $33.94 \mathrm{bc}$ & 68 & $56.06 \mathrm{ab}$ \\
Bio-arc & 40 & $39.01 \mathrm{ab}$ & 60 & $51.00 \mathrm{bc}$ \\
$\begin{array}{c}\text { Cont A. With } \\
\text { water }\end{array}$ & 68 & $55.84 \mathrm{a}$ & 32 & $34.17 \mathrm{c}$ \\
\hline
\end{tabular}

* The data were transformed by using arcsine formula.

${ }^{*} \mathrm{R} .=$ Reduction percentage of the disease incidence

* In T= Transformed data for disease incidence

${ }^{*} \mathrm{HT}=$ Transformed data for fruits healthy unit

\section{DISCUSSION}

Citrus fruit rot disease incited by $A$. citri is one of the serous diseases which attack citrus cultivars causing severe damage whereas causing many diseases on citrus, i.e. black fruit rot, stem end rot, brown spot and leaf spot (Farooqi et al 1985; Solel, 1991; Brown and Eckert, 2000; Katoh et al 2006 and Kono, et al 2015). Chemical control results indicated that, $A$. citri was more affected 
fungus with three fungicides namely, Score, Montoro and Iprodione were the best fungicides based on (Ec. 50 and Ec. 90) and no observed growth of the causal fungus when these selective concentrations were used in vitro whereas at Ec. 90 were found to be $96.89,96.89$ and 329.01 respectively, and the same trend was observed in vivo trials and the reduction percentage of the disease incidence was $96.00,96.00$ and $92.00 \%$ respectively, while, coprax, coprareekh, and azoxystrobine were the lowest effective fungicides against isolate of $A$. citri (K2) causing citrus fruit rot disease in vitro and the same trend was observed in vivo trials and the reduction percentage of the disease incidence was $80.00,80.00$ and $64.00 \%$ respectively. While, Pyraclsotrobin was moderate effective when used against the pathogenic Alternaria isolate and the reduction percentage of disease incidence was $(88 \%)$ and the disease incidence average was $(12 \%)$ when was used in vivo trial level. This result agrees with the authors (Timmer \& Zitko, 1992, 1994, 1997; Solel et al 1997 and Swart et al 1998), they found that, Iprodione is very effective against Alternaria disease control. Other fungicides that are effective and registered in Israel are the dithiocarbamates, triazoles, and famoxadon. Azoxystrobine and pyraclostrobine are generally more effective than trifloxystrobin. The strobilurin fungicides are single site of action fungicides and also, have been evaluated and proven effective for control of Alternaria brown spot (Timmer et al 2003). In vitro and in vivo trials Alternaria alternata, Penicillium digitatum and Alternaria citri, was greatly suppressed by Difenoconazole at $150 \mathrm{ppm}$ (Monir and Salaheldin, 2016).

Biological control is widely used in controlling soil-borne and fruit rot disease in many fruit crops (Jefferson et al 2000; Arrebola et al 2010 and Ferdousi-Begum et al 2010). The obtained data showed that, the tested bioagents were effective against the tested causal pathogen of citrus fruit rot disease. In vitro studies proved that Trichoderma harzianum isolated was found highly effective in suppressing as abioagent against the tested causal pathogenic Alternaria isolate (Code, K2) followed by volatile of Trichoderma harzianum then Bacillus subtilis the reduction percentage of the growth was $86.44,86.66$ and $69.44 \%$ respectively. In vivo studies also, showed that $T$. harzianum was the most effective bioagent against Alternaria isolate (Code, K2) followed by Bacillus subtilis then omega whereas the reduction percentage of disease incidence was 76,84 and $72 \%$. Whilst, $B$. megaterium (Bio-ARC) and T. album (Bio-Zeid) were the least effective bioagent against Alternaria isolate (Code, K2) the causal pathogen of citrus fruit rot, reduction percentage of disease incidence was 68 and $60 \%$ respectively. These results are in agreement with Rachniyow and Jaenaksorn (2008) who found that, Trichoderma spp., are common inhabitants of the rhizosphere as biocontrol against soil-borne plant pathogens. Commendable amount of researches have been focused on the mycoparasitic nature of genus Trichoderma and its contribution to plant health. Several mechanisms have been considered to be key factors in antagonistic interactions, i.e. lysis of host cell walls, antibiosis, competition for nutrients, induced resistance in plants and inactivation of host enzymes. Mixed cultures of the microbial antagonists appear to provide better control of postharvest diseases. At the international level, different microbial antagonists i.e. Debaryomyces hansenii, Cryptococcus laurentii B. subtilis and $T$. harzianum were used against and suppress the activity of post-harvest pathogens in fruit and vegetables (Sharma et al 2009).

This may be lead to disease escape or to higher tolerance against soil-borne and air-borne pathogens. B. megaterium, $B$. cereus and $B$. subtilis have been used for the biocontrol purpose. The activity of biocontrol agents against soil-borne disease is important to achieve successful control activity (Lee et al 2008 and Hye-Sook et al 2009).

\section{REFFERENCES}

Al-Hassan, K.K. and Najlah, N.A. 1982. Laboratory test to evaluate the effectiveness of some fungicides against certain soil-borne fungi. J. Sci., 23 (3), 431-442.

Arrebola, E.; Jacobs, R. and Korsten, L. 2010. Iturin $\mathrm{a}$ is the principle inhibitor in the biocontrol activity of Bacillus amyloliquefaciens PPCB004 against post-harvest fungal pathogens. J., Applied Microbiology. 108, 386-395.

Bhatia, A., Roberts, P.D. and Timmer, L.W. 2003. Evaluation of the Alter-Rater model for timing of fungicide applications for control of Alternaria brown spot of citrus. Plant Diseases, 87, 1089-1093pp.

Brown, G.E. 1994. Alternaria stem end rot. Univ., Flo., IFAS Extension, pp. 1-2.

Brown G.E. and Eckert, J.W. 2000. Alternaria rot. In: Compendium of Citrus Diseases, $2^{\text {nd }}$ edition. (Timmer, L.W. Garnsey, S.M. and Graham, J.H. ed.), APS Press, St. Paul, MN, USA, 38 p. 

rot on citrus fruits

Commonwealth of Australia, 2002. Citrus Imports from the Arab Republic of Egypt.

Duncan, D.B.1955. Multiple ranges and multiple F. test. Biometerics, 11, 1-42.

El-Zayat, M.M.; El-Tobshy, Z.M., Abo-Elata, U., Harfoush, D. and Sayed, M.K. 1983. Alternaria citri and June fruit drop of navel orange. Agricultural Research Review. 61(2),1-18.

Farooqi, W.A., Malik, M.A., Shaukat, G.A. and Ahmad, M.S. 1985. Influence of ph the growth of Alternaria citri on citrus fruit juice. Proc. Fla. State Hort. Soc., 98, 214-215.

Ferdousi-Begum, M.; Rahman, M.A. and FirozAlam, M. 2010. Biological control of Alternaria fruit rot of Chili by Trichoderma species under field conditions. Mycobiology. 38(2), 113-117.

Gveroska, B. and Ziberoski, J. 2012. Trichoderma harzianum as a biocontrol agent against $A /$ ternaria alternata on tobacco. Applied Technologies and Innovations, 7(2), 67-76.

Gomez, K.A. and Gomez, A.A. 1984. Statistical procedures for Agricultrural Research. John Wiley and Sons, Inc. New York, USA.

Hye-Sook, K., Sang, M.K., Myung, I.S., Chun, S.C. and Kim, K. 2009. Characterization of Bacillus luciferensis strain KJ2C12 from pepper root a biocontrol agents of Phytophthora blight of pepper. Plant Pathology, J., 25(1), 62-69.

Jakovljević, V.D., Stojanović, J.D. and Vrvić, M.M. 2015. The potential application of fungus Trichoderma harzianum rifai in biodegradation of detergent and industry. Chem. Ind. Chem. Eng. Q. 21(1), 131-139.

Jefferson, L., Costa, daS., Menge, J.A. and Casale, W.L. 2000. Biological control of Phytophthora root-rot of avocado with microorganisms grown in organic muleshes. Brazilian $\mathbf{J}$. of Microbiology, 31, 2 39-246.

Katoh, H., Isshiki, A., Masunaka, A., Yamamoto, H. and Akimitsu, K. 2006. A virulence reducing mutation in the postharvest citrus pathogen Alternaria citri. Phytopathology. 96, 934-940.

Kono, Y., Gardner, J.M., Suzuki, Y. and Takeuchi, S. 2015. Studies on host-selective toxins produced by a pathotype of Alternaria citri causing brown spot disease of mandarins. Agric. Biol. Chem., 50(6), 1597-1606.

Lee, K.J., Kamala-Kannan, S., Sub, H.S., Seong, C.K. and Lee, G.W. 2008, Biological control of Phytophthora blight in red pepper (Capsicum annuum L.) using Bacillus subtilis. World J. Microbiol. Biotechnol., 24,1139-1145.
Manner, H.I., Buker, R.S., Smith, V. E., Ward, D. and Elevitch, C.R. 2006. Citrus spp. (citrus) and Fortunella (kumquat). Species Profiles for Pacific Island Agroforestry, 35 p.

Monir, A. and Salaheldin, T.A. 2016. Silver nanoparticles as a potent fungicide for citrus phytopathogenic fungi. J. of Nanomedicine Research, 3(5), 1-8.

Murtaza, S., Anjum T. and Shafique, S. 2012. In -vitro control of Aternaria citri using antifungal potentials of Trichoderma species. African J. of Biotechnology,11(42), 9985-9992.

Reis, R.F., de-Goes, A., Mondal, S.M. and Timmer, L.W. 2006. Effectiveness of fungicides and susceptibility of fruit and leaves of tangerines, tangor and tangelos to infection by Alternaria alternata, the cause of brown spot. Summa Phytopathologica Supl., pp. 11-12.

Rachniyom, H. and Jaenaksorn, T. 2008. Effect of soulible, silicon and Trichoderma harzianum on the in vitro growth of Pythium aphanidermatum, J. of Agric. Technology, 4(2), 57-71.

Sharma, R.R., Singh, D. and Singh, R. 2009. Biological control of post-harvest disease of fruit and vegetables by microbial antagonists. Biol. Control. 50, 205-221.

Sharvell, M.V. 1962. Persistence of benomyl in pruned apricot sapwood. Australian J. of Agric. Res., 26(3), 529-536.

Siameto, E.N., Okoth, S., Amugune, N.O. and Chege, N.C. 2010. Antagonism of Trichoderma farzianum isolates on soil borne plant pathogenic fungi from Embu District, Kenya. Journal of Yeast and Fungal Research. 1(3), 4754.

Singh, V. and Deverall, B.J. 2006. Bacillus subtilis as a control agent against fungal pathogens of citrus fruit. Transactions of the British Mycological Society. 83(3), 487-490.

Solel, Z. 1991. Alternaria brown spot on Minneola tangelos in Israel. Plant Pathol. 40,145-147.

Solel, Z., Timmer, L.W. and Kimchi, M. 1996. Iprodione resistance of Alternaria alternata pv. citri from Minneola tangelo in Israel and Florida. Plant Disease 80, 291-293.

Solel, Z., Oren, Y. and Kimchi, M. 1997. Control of Alternaria brown spot of Minneola tangelo with fungicides. Crop Protection. 16, 659-664.

Swart, S.H., Wingfield, M.J., Swart, W.J. and Schutte, G.C. 1998. Chemical control of Alternaria brown spot on Minneola tangelo in South Africa. Ann. Appl. Bid. 133, 17-30. 
Timmer, L.W. and Zitko, S.E. 1992. Evaluation of fungicides for control of citrus scab. Fungicide and Nematicide Tests. 47, 334.

Timmer, L.W. and Zitko, S.E. 1994. Evaluation of fungicides for control of Alternaria brown spot. Fungicide and Nematicide Tests. 49, 380.

Timmer, L.W. and Zitko, S.E. 1997. Evaluation of fungicides for control of Alternaria brown spot and citrus scab. Proceedings of the Florida State Horticultural Society. 110, 71-76.

Timmer, L.W. 1998. Pre-harvest of citrus disease in Florida. University of Florida, IFAS. pp. 137144.

Timmer, L.W., Peever, T.L., Solel, Z. and Akimitsu, K. 2003. Alternaria diseases of citrus - novel pathosystems. Phytopathol. Mediterr., 42, 3-16.
Van-Zyl, J.G., Fourie, P.H. and Schutte, G.C. 2013. Spray deposition assessment and benchmarks for control of Alternaria brown spot on mandarin leaves with copper oxychloride. Crop Protection. 46, 80-87.

Vicent, A., Armengol, J. and García-Jiménez, J. 2007. Rain fastness and persistence of fungicides for control of Alternaria brown spot of citrus. Plant Dis., 91, 393-399.

Vicent, A., Armengo, J. and Garcia-Jime'nez, J. 2009. Protectant activity of reduced concentration copper sprays against Alternaria brown spot on 'Fortune' mandarin fruit in Spain. Crop Protection. 28, 1-6.

Whiteside, J.O. 1979. Alternaria brown spot of Dancy tangerines and its control. Proc. Fla. State Hort., Soc., 92, 34-37. 